\title{
KONTRIBUSI KECEPATAN LARI 30 METER DAN EXSPLOSIVE POWER OTOT TUNGKAI TERHADAP KEMAMPUAN LOMPAT JAUH
}

\author{
Popalri \\ STKIP PGRI Lubuklinggau, Indonesia
}

\begin{abstract}
ABSTRAK
Tujuan penelitian ini adalah untuk mengetahui seberapa besar kontribusi kecepatan lari 30 meter dan exsplosive power otot tungkai terhadap hasil lompat jauh. Penelitian ini merupakan penelitian korelasional dilanjutkan dengan melihat kontribusi variabel $\mathrm{X}$ terhadap variabel $\mathrm{Y}$. Populasi dalam penelitian ini adalah mahasiswa yang mengikuti perkuliahan atletik yang berjumlah 32 orang.Yang dijadikan sampel mahasiswa putra saja berjumlah 30 orang, Dengan menggunakan teknik pengambilan sampel purposive sampling. Penelitian ini dilakukan pada bulan Oktober 2016/2017, bertempat di Stadion Silampari Lubuklinggau dan dilapanganLompat Jauh STKIP-PGRI Lubuklinggau. Dari hasil penelitian ini diperoleh kontribusi variabel kecepatan lari 30 meter terhadap kemampuan lompat jauh sebesar 27,64\%, kontribusi exsplosive power otot tungkai terhadap kemampuan lompat jauh sebesar 16,92\%, dan kontribusi kecepatan lari 30 meter dan exsplosive power otot tungkai secara bersama-sama terhadap kemampuan lompat jauh sebesar $31,00 \%$.
\end{abstract}

Kata Kunci: Kecepatan, Explosive Power, Lompat Jauh.

\section{PENDAHULUAN}

Lembaga pendidikan tinggi merupakan jenjang pendidikan setelah pendidikan menengah yang mengcangkup program pendidikan diploma, sarjana, magister, spesialis, dan doktor yang diselenggarakan oleh perguruan tinggi. Tiga ciri khas perguruan tinggi adalah: (a) academic community, (b) academic athmosphere, dan (c) academic freedom. Tenaga pendidikan di perguruan tinggi terdiri atas dosen dan tenaga penunjang akademik, dan anak didiknya disebut mahasiswa.Salah satu lembaga pendidikan negeri yang berperan penting dalam meningkatkan sumber daya manusia di bidang olahraga dan kesehatan jasmani adalah program studi Pendidikan jasmani kesehatan dan rekreasi STKIP-PGRI Lubuklinggau.

Di Indonesia, olahraga dimasyarakatkan tidak hanya untuk kepentingan kependidikan, rekreasi, dan kesegaran jasmani, tetapi juga sebagai ajang prestasi. 
Hal ini dijelaskan dalam Undang-undang RI Nomor 3 Tahun 2005 tentang Sistem Keolahragaan Nasional. Pada BAB II Pasal 4 dijelaskan sebagai berikut:

"Keolahragaan nasional bertujuan memelihara dan meningkatkan kesehatan dan kebugaran, prestasi, kualitas manusia, menanamkan nilai moral dan akhlak yang mulia, sportivitas, disiplin, mempererat dan membina persatuan dan kesatuan bangsa, memperkukuh ketahanan nasional, serta mengangkat harkat, martabat dan kehormatan bangsa".

Olahraga adalah unsur penting dan strategis dalam proses pembangunan bangsa dalam rangka peningkatan kualitas/sumber daya manusia Indonesia, maupun pembangunan kekuatan ekonomi, social budaya, politik, pertahanan dan keamanan, dalam upaya peningkatan produktivitas dan efisiensi nasional, guna menyikapi dan mengatasi tantangan serta memanfaatkan peluang dalam peradaban manusia yang semakin global.

Program studi pendidikan jasmani kesehatan dan rekreasi STKIP-PGRI Lubuklinggau adalah sebagai wadah pusat pengkajian ilmu keolahragaan yang menggali dan mengembangkan serta memelihara ilmu pengetahuan dan teknologi keolahragaan dan memperluas hasil-hasilnya agar bisa dimanfaatkan sebesarbesarnya bagi masyarakat.

Program studi pendidikan jasmani kesehtan dan rekreasi STKIP-PGRI Lubuklinggau yang selalu terbuka dalam ide-ide pembaharuan dan kerjasama dengan berbagai pihak guna menghimpun segala sumber daya agar meningkatkan kualitas pengabdiannya dalam bidang keolahragaan dan selalu berorientasi ke masa depan guna memenuhi tuntutan pembangunan nasional, sehingga menjadi lembaga yang handal dan produktifitas dalam melaksanakan Tri Dharma Perguruan Tinggi

Berdasarkan uraian diatas, jelaslah bahwa program studi pendidikan jasmani kesehatan dan rekreasi STKIP-PGRI Lubuklinggau merupakan salah satu lembaga pendidikan di Kota Lubuklinggau, bertujuan untuk menghasilkan tenaga kependidikan bidang olahraga yang profesional.Maksud profesional disini adalah mampu menghasilkan lulusan yang memiliki berbagai keterampilan berolahraga serta menguasai ilmu pengetahuan lainya yang berhubungan dengan olahraga dan kesehatan. Di samping itu juga lulusan program studi pendidikan jasmani STKIPhttp://ojs.stkippgri-lubuklinggau.ac.id/index.php/JPP 
PGRI Lubuklinggau dapat menghasilkan calon pelatih, penerima jasa pengelola pertandingan, pengelola manajemen olahraga dan sebagai wirausahawan yang berguna bagi kehidupan pribadi, keluarga dan orang lain serta masyarakat Indonesia.

Berdasarkan observasi di lapangan di saat perkuliahan atletik, umumnya mahasiswa Program studi pendidikan jasmanai kesehatan dan rekkreasi STKIPPGRI Lubuklinggau ditemui rendahnya hasil dari lompat jauh tersebut di lihat dari hasil nilai ujian semester mahasiwa Pendidikan Olahraga tahun 2016 yang mengambil mata kuliah atletik dasar. Padahal dilihat dari postur badan dan panjangnya otot tungkai sangat bagus untuk mendapatkan hasil lompat jauh yang bagus, seharusnya mahasiswa Fakultas Ilmu Keolahragaan tersebut kalau dilatih bisa menghasilkan atlet atletik yang berprestasi, bahwasanya untuk menghasilkan lompatan yang maksimal di tunjang dengan tinggi badan, kecepatan, daya ledak otot tungkai, koordinasi gerakan, ayunan tangan, sikap badan di udara dan letak kaki tumpuan.

Dalam ilmu fisika, kecepatan didefinisikan sebagai jarak per satuan waktu. Kecepatan merupakan salah satu unsur penting pada beberapa cabang olahraga tertentu, seperti: atletik pada nomor lari, sepak bola, renang, dan sebagainya. Pengertian dari kecepatan lari secara sederhana dapat diartikan kecepatan lari yang dicapai oleh seseorang dalam waktu tertentu, jadi kecepatan lari sebenarnya tidak lepas dari pengertian kecepatan. Menurut kusyanto (1994:83 ) "kecepatan adalah kemampuan untuk melakukan gerakan-gerakan yang sejenis secara berturut-turut dalam waktu yang sesingkat-singkatnya, atau kemampuan untuk menempuh suatu jarak dalam waktu yang sesingkat-singkatnya, atau kemampuan untuk menempuh suatu jarak dalam waktu yang sesingkat.

Kecepatan merupakan kemampuan fisik yang esensial dan merupakan faktor penentu pada bagian besar cabang olahraga seperti nomor lari, lompat jauh, dan beberapa cabang olahraga permainan. Kecepatan bergerak adalah kualitas yang memungkinkan orang yang bergerak atau melaksanakan gerakan-gerakan yang sama atau berlainan secepat mungkin. Menurut Corbin (1980: 86), 
Kecepatan adalah kemampuan melangkah dari suatu tempat ketempat lain dalam waktu sesingkat mungkin.

Selama tiga sampai lima langkah terakhir pelompat mempersiapkan diri untuk mengalihkan awalan/ kecepatan horizontal kepada tolakan/ kecepatan vertikal, pada saat itu kecepatan tidak berkurang. Satu langkah sebelum yang terakhir, kira-kira 10-15 cm dua kali lebih panjang dari langkah sebelumnya dan yang terakhir. Karena titik berat badan akan terbawa ke bawah. (Jonath, 1986:197).

Faktor penunjang keberhasilan dalam mencapai prestasi olahraga yang tinggi diantaranya adalah faktor Eksplosive power yang merupakan komponen fisik yang terjadi dari gabungan kekuatan dan kecepatan. Hampir semua cabang olahraga memerlukanEksplosivepower. Untuk itu Eksplosive power harus diberikan kepada olahragawan dalam usaha meningkatkan prestasi. Dalam melakukan teknik-teknik yang baik, khususnya pada cabang olahraga lompat sangat dibutuhkan sekali Eksplosivepower yaitu: tenaga yang digunakan pada saat start atau tolakan kaki pada saat start.Arsil (1999 : 71), Daya Ledak adalah kekuatan kecepatan kontraksi otot secara dinamis, eksflosif dalam waktu yang cepat. Menurut Harre dalam Syafruddin (1999: 37) bahwa " Daya Ledak adalah kemampuan atlet untuk mengatasi tahanan dengan suatu kecepatan kontraksi tinggi. Kontraksi otot yang tinggi diartikan sebagai kemampuan otot yang kuat dan cepat dalam berkontraksi”.

Pada cabang olahraga atletik pada nomor lompat jauh Eksplosive power otot tungkai merupakan tumpuan utama yang merupakan penentu dalam hasil lompatan. Apabila pelompat ingin memperoleh keuntungan melakukan lompatan start dengan tepat, memiliki daya jangkau yang jauh dan tepat, hendaknya pada saat melakukan start banyak memperhatikan sikap hidrodinamis, dimana berusaha untuk masuk dengan mengurangi resiko ketahanan yang sedikit mungkin.

Disamping tungkai yang panjang dan otot yang bagus juga menunjang terhadap pencapaian prestasi yang maksimal dalam cabang olahraga lompat, pada saat lompatan start ketika melakukan dorongan kencang dari atas pada pantat dan otot paha serta berlanjut untuk melepas ujung jari dan pergelangan kaki sangat http://ojs.stkippgri-lubuklinggau.ac.id/index.php/JPP 
dibutuhkan Eksplosive power otot tungkai keseluruhan, sehingga menciptakan daya dorong yang maksimal dan mengshasilkan lompatan yang jauh ke depan. Begitu juga sebaliknya tanpamemiliki Eksplosive power otot tungkai yang baik akan mempengaruhi jauhnya lompatan pada saat start dalam melakukan lompatan.

Lompat jauh merupakan salah satu nomor lompat dari cabang olahraga atletik. Lompat jauh menurut Syarifuddin (1992: 90) didefinisikan sebagai "suatu bentuk gerakan melompat, mengangkat kaki keatas kedepan dalam upaya membawa titik berat badan selama mungkin diudara (melayang diudara) yang dilakukan dengan cepat dan dengan jalan melakukan tolakan pada satu kaki untuk mencapai jarak yang sejauh-jauhnya”.

Lompat jauh merupakan suatu gerakan melompat menggunakan tumpuan satu kaki untuk mencapai jarak sejauh-jauhnya. Sasaran dan tujuan lompat jauh adalah untuk mencapai jarak lompatan sejauh mungkin kesebuah letak pendaratan atau bak lompat. Jarak lompatan diukur dari papan tolakan sampai batas terdekat dari letak pendaratan yang dihasilkan oleh bagian tubuh. Dalam lompat jauh terdapat beberapa macam gaya yang umum dipergunakan oleh para pelompat, yaitu : gaya jongkok, gaya menggantung atau disebut juga gaya lenting dan gaya jalan di udara. "Perbedaan antara gaya lompatan yang satu dengan yang lainnya, ditandai oleh keadaan sikap badan si pelompat pada waktu melayang di udara" Syarifuddin (1992:93). Awalan tumpuan/tolakan dan cara melakukan pendaratan dari ketiga gaya tersebut pada prinsipnya sama. Salah satu gaya yang digunakan dalam penelitian ini adalah gaya jongkok.

\section{METODE}

Penelitian ini adalah penelitian korelasi (correlation research). Menurut Sudjana (1996: 367) bahwa" Penelitian korelasi merupakan penelitian untuk mengetahui ada tidaknya hubungan dua variabel, besar atau tingginya hubungan tersebut dinyatakan dalam bentuk koefisien korelasi”. Dalam penelitian ini variabel bebasnya adalah kecepatan dan eksplosive power otot tungkai, sedangkan variabel yang diprediksi atau variabel terikatnya adalah kemampuan lompat jauh. 
Untuk mendapatkan hasil penelitian maka dilakukan tes yaitu kecepatan dilakukan dengan tes lari 30 meter, untuk explosive power digunakan tes standing broad jump kemudian tes kemampuan lompat jauh dengan tes lompat jauh.Data yang diperoleh nanti akan diolah dengan Uji normalitas dengan menggunakan liliefors. Uji normalitas bertujuan untuk mengetahui data yang diperoleh apakah berdistribusi normal atau tidak.Kemudian dilakukan pengolahan data menggunakan product moment dengan teknik korelasi ganda.

\section{HASIL DAN PEMBAHASAN}

\section{HASIL}

\section{Uji Normalitas}

Uji normalitas data dilakukan dengan uji lilliefors. Hasil analisis uji normalitas masing-masing variabel di sajikan dalam bentuk tabel di bawah ini.

Tabel 1. Uji normalitas data dengan uji lilliefors

\begin{tabular}{|l|l|c|c|l|}
\hline No & \multicolumn{1}{|c|}{ Variabel } & Lo & Lt & Keterangan \\
\hline 1 & Kecepatan Lari 30 meter & 0.103 & 0.161 & Normal \\
\hline 2 & Exsplosive Power otot tungkai & 0.138 & 0.161 & Normal \\
\hline 3 & Kemampuan Lompat Jauh & 0.157 & 0.161 & Normal \\
\hline
\end{tabular}

Pada tabel di atas dapat dilihat bahwa hasil Lo variabel kecepatan lari 30 meter, exsplosive power otot tungkai dan kemampuan lompat jauh, lebih kecil dari Lt, maka dapat disimpulkan bahwa data berdistribusi normal.

\section{Perhitungan Koofisien Korelasi Sederhana}

Hasil pehitungan koefisien korelasi sederhana dapat dilihat sebagai berikut:

1. Hasil hitung koefisien koralasi nilai $\mathrm{X}_{1}$ terhadap $\mathrm{Y}$ adalah 0,526

2. Hasil hitung koefisien koralasi nilai $\mathrm{X}_{2}$ terhadap $\mathrm{Y}$ adalah 0,411 


\section{PEMBAHASAN}

\section{Kontribusi Kecepatan Lari 30 Meter $\left(\mathrm{X}_{1}\right)$ terhadap Hasil Lompat Jauh}

Berdasarkan analisis data dan pengujian hipotesis pertama yang telah dikemukakan pada bagian sebelumnya, kecepatan kecepatan lari 30 meter memiliki kontribusi yang signifikan.Hal ini dapat dilihat dalam perhitungan korelasi antara kecepatan lari 30 meter $\left(\mathrm{X}_{1}\right)$ dengan kemampuan lompat jauh (Y) menggunakan rumus korelasi product moment.Kriteria pengujian jika $r_{\text {hitung }}>r_{\text {tabel}}$, maka terdapat hubungan yang signifikan dan sebaliknya (Sudjana 2002:369). Hasil yang telah didapat pada pengujian hipotesis $r_{\text {hit }}(0.526)>r_{\text {tab }}(0.3 .01)$, berarti terdapat kontribusi yang signifikan antara kecepatan lari 30 meter dengan kemampuan lompat jauh mahasiswa Penjaskesrek STKIP-PGRI Lubuklinggau.

Dari hasil perhitungan korelasi antara kecepatan lari 30 meter dengan kemampuan lompat jauh diperoleh $t_{\text {hitung }}(2,270)$ sedangkan $t_{\text {tabel }}$ pada taraf signifikan $\alpha=0.05$ yaitu 1,701 . Berarti dalam hal ini terdapat kontribusi antara kecepatan lari 30 meter dengan kemampuan lompat jauh.

\section{Kontribusi Exsplosive Power Otot Tungkai (X2) terhadap Kemampuan Lompat Jauh}

Berdasarkan analisis data dan pengujian hipotesis yang telah dikemukakan pada bagian sebelumnya, daya ledak otot tungkai dengan hasil lompat jauh memiliki hubungan yang signifikan.Perhitungan korelasi antara daya ledak otot tungkai $\left(\mathrm{X}_{1}\right)$ dengan hasil lompat jauh $(\mathrm{Y})$ menggunakan rumus korelasi product moment.Kriteria pengujian jika $r_{\text {hitung }}>r_{\text {tabel}}$, maka terdapat hubungan yang signifikan dan sebaliknya (Sudjana 2002:369). Dari hasil perhitungan korelasi antara daya ledak otot tungkai dengan hasil lompat jauh diperoleh $t$ hitung 0,526 sedangkan $t_{\text {tabel }}$ pada taraf signifikan $\alpha=0.05$ yaitu 0,361 . Berarti dalam hal ini terdapat kontribusi signifikan antara daya ledak otot tungkai dengan hasil lompat jauh memilikihubungan yang besar, dengan demikian semakin baik daya ledak otot tungkai yang dimiliki mahasiswa Penjaskesrek STKIP-PGRI Lubuklinggau maka semakin baik pula hasil lompat jauhyang diperoleh. 


\section{Kontribusai Kecepatan Lari 30 Meter dan Exsplosive Power Otot Tungkai secara Bersama-sama terhadap Kemampuan Lompat jauh}

Hasil analisis korelasional ganda mengindikasikan bahwa terdapat kontribusi yang signifikan antara kecepatan lari 30 meter $\left(\mathrm{X}_{1}\right)$ dan exsplosive power otot tungkai $\left(\mathrm{X}_{2}\right)$ secara bersama-sama terhadap kemampuan lompat jauh (Y). Kriteria pengujian signifikan dengan uji $F$ (sudjana, 2002: 385).Jika $f_{\text {hitung }}>f$ tabel maka terdapat hubungan dan sebaliknya tidak terdapat hubungan jika $\mathrm{f}_{\text {hitung }}<$ $\mathrm{f}_{\text {tabel. }}$. Dari hasil perhitungan diperoleh koefisien korelasi ganda (uji F) didapat $\mathrm{F}$ hitung $=6.06$ sedangkan $\mathrm{F}_{\text {tabel }}$ diperoleh dengan $\mathrm{N}-\mathrm{K}-1 / 20-2-1=28$ sebesar 3,35 jadi $F_{\text {hitung }}>F_{\text {tabel, }}$, selanjutnya hasil perhitungan $R($ korelasi berganda) secara bersama-sama tingkat kontribusi kecepatan lari 30 meter $\left(\mathrm{X}_{\mathrm{I}}\right)$ dan exsplosive power otot tungkai $\left(\mathrm{X}_{2}\right)$ dengan kemampuan lompat jauh $(\mathrm{Y})$ sebesar 0,56 dan perhitungan R2 (square) atau koefisien determinan berganda memberikan sumbangan secara bersama-sama kedua variabel bebas ini $\left(\mathrm{X}_{1}\right.$ dan $\left.\mathrm{X}_{2}\right)$ terhadap kemampuan lompat jauh (Y) mahasiswa Penjaskesrek STKIP-PGRI Lubuklinggau ditentukan oleh variabel-variabel yang lain.

\section{KESIMPULAN}

Berdasarkan dari hasil penelitian yang telah penulis uraikan pada bab terdahulu, maka dapat diambil kesimpulan sebagai berikut

1. Kecepatan lari 30 meter mempunyai kontribusi positif terhadap kemampuan lompat jauh mahasiswa Pendidikan Jasmani Kesehatan dan Rekreasi STKIPPGRI Lubuklinggau sebesar 27,64\%.

2. Exsplosive power otot tungkai mempunyai kontribusi positif terhadap kemampuan lompat jauh mahasiswa Pendidikan Jasmani Kesehatan dan Rekreasi STKIP-PGRI Lubuklinggau sebesar 16,92\%.

3. Terdapat kontribusi positif secara bersama-sama antara kecepatan lari 30 meter dan exsplosive power otot tungkai terhadap kemampuan lompat jauh mahasiswa Pendidikan Jasmani Kesehatan dan Rekreasi STKIP-PGRI Lubuklinggau sebesar 31,00\%. 


\section{DAFTAR PUSTAKA}

Arsil. (1999). Pembinaan Kondisi Fisik. Padang: FIK UNP.

Corbin. CB. (1980). A Text Book Of Motor Development. Lowa:Wmc. Brown Company Publisher Dubuque.

Kementerian Negara Pemuda dan Olahraga RI.No. 3.(2005). Tentang Sistem Keolahragaan Nasional. Jakarta: Presiden Republik Indonesia.

Kusyanto, Yanto. (1994). Pendidikan jasmani dan kesehatan. Bandung. Ganeca Exact.

Sudjana ,Nana. (1999). Dasar-Dasar Proses Belajar Mengajar . Bandung : Sinar Baru Algesindo.

Syafruddin. (1999). Ilmu kepelatihan olahraga. Padang: UNP Press

Syarifuddin, AIP. (1992). Atletik. Jakarta: Departeman pendidikan dan kebudayaan.

U. Jonath. (1986). Atletic II, P2LPTK. USA: Luxbacer. 